\title{
PENGARUH PROMOSI JABATAN DAN KOMPENSASI TERHADAP MOTIVASI SERTA IMPLIKASINYA TERHADAP PRODUKTIVITAS KERJA KARYAWAN PADA PERUSAHAAN MANUFAKTUR DI CIKARANG
}

\section{Oleh :}

Witarman

witarman78@gmail.com

\begin{abstract}
This study aims to explain the influence of promotion and employee compensation to employee motivation that have implications on work productivity of manufacturing company in cikarang, in this study the sample used as many as 120 people with positions foreman and junior section head section production of manufacturing company in Cikarang. Data collection is done through direct observation, questionnaires, library research obtained through interviews and internal data collection of companies and relevant references. This research uses explanatory research type with quantitative approach. Method of data analysis using descriptive analysis method with path analysis. The result of the research shows that job promotion has a significant effect on work motivation 26,7\%, compensation has significant effect to work motivation equal to $16,4 \%$, and work motivation have significant effect to work productivity 22,8\%, on the productivity of work has a significant effect of $8 \%$ smaller than the indirect effect of 54\% through motivation, compensation does not directly affect the productivity of work and promotion positions, compensation and motivation simultaneously have a significant effect on work productivity of $61.9 \%$ while $38.1 \%$ is another influence that is not examined.
\end{abstract}

Keywords: Motivation, Job Promotion, Compensation and Productivity

54. 


\section{Pendahuluan}

Sumber daya manusia merupakan faktor yang sangat penting bagi suatu organisasi atau perusahaan, baik yang bergerak dalam bidang produksi maupun dalam bidang pelayanan jasa. Setiap organisasi pemerintah maupun swasta dituntut bekerja lebih cepat, efektif dan efisien. Untuk itu, faktor sumber daya manusia perlu mendapat prioritas utama dalam pengelolaannya agar pemanfaatannya sesuai dengan yang diharapkan oleh organisasi. Pengelolaan sumber daya manusia berbeda dengan faktor produksi lainnya dikarenakan sumber daya manusia selalu berkembang dan bertambah, baik kuantitas maupun kualitasnya. Untuk dapat memanfaatkan sumber daya manusia sesuai dengan kebutuhan organisasi, diperlukan manajemen sumber daya manusia yang dapat mengatur berjalannya suatu organisasi. Oleh karena itu perusahaan harus mampu membentuk sumber daya manusianya untuk lebih terampil dan ahli dibidangnya sehingga tujuan perusahaan dapat tercapai sesuai dengan waktu yang telah ditetapkan. Suatu organisasi juga harus mampu menyusun kebijakan yang tepat untuk mengatasi setiap perubahan yang akan terjadi. Penyusunan kebijakan yang menjadi perhatian manajemen salah satunya menyangkut pemberdayaan sumber daya manusia. Sumber daya manusia yang pontensial apabila didayagunakan secara efektif dan efisien akan bermanfaat untuk menunjang gerak lajunya perusahaan (Koesmono, 2006).

Upaya menunjang gerak lajunya perusahaan tersebut adalah dengan meningkatkan produktivitas kerja karyawan. Sebab Keberhasilan perusahaan salah satunya ditandai dengan meningkatnya produktivitas. Produktivitas kerja yang tinggi merupakan salah satu keunggulan kompetitif perusahaan. Peningkatan produktivitas bisa dilakukan dengan berbagai cara sebagai faktor pendorong untuk mencapai hal tersebut. Secara teoritis produktivitas kerja seorang karyawan dipengaruhi oleh berbagai faktor diantaranya adalah faktor Promosi, faktor kompensasi dan faktor motivasi (Anoraga, 2001). Hal tersebut yang mendasari sebuah organisasi atau perusahaan harus bisa lebih mementingkannya dalam upaya melakukan pembenahan agar mampu mencapai target sesuai dengan apa yang diharapkan.

Produktivitas yang tinggi merupakan hal utama yang ingin dicapai oleh setiap perusahaan dalam setiap rencana yang ada. Dalam hal ini, peranan karyawan sangat penting dan berarti. Namun demikian, perusahaan tidak dapat menafsirkan bahwa keterlibatan karyawan secara utuh dan efektif tidak akan berguna tanpa adanya loyalitas yang tinggi dari setiap karyawan yang terlibat dalam peningkatan produktivitas perusahaan. Namun, perusahaan tidak dapat mengindahkan bahwa segala pengabdian dan kerja keras yang telah dilakukan perusahaan harus diikuti dengan penghargaan dari perusahaan, Salah satu bentuk penghargaan perusahaan terhadap para karyawannya antaralain dalam bentuk promosi jabatan sehingga peningkatan produktivitas perusahaan berlangsung secara terus menerus.

Promosi adalah kemajuan yang diperoleh sebagai pegawai pada suatu tugas yang lebih baik, lebih baik dimaksud dipandang dari sudut tanggung jawab yang lebih berat martabat atau status yang lebih tinggi, kecakapan yang lebih baik, dan yang terpenting adalah penambahan jumlah gaji atau upah, Moekijat (1999:101). Moekijat menjelaskan bahwa promosi yang diperoleh oleh seorang karyawan dipandang sebagai suatu kemajuan. Dimana karyawan akan memiliki suatu pencapaian tugas dan pekerjaan yang lebih baik. Karyawan akan menerima tanggung jawab dan tugas yang

55.

Jurnal Manajemen \& Bisnis Kreatif 
lebih tinggi, tetapi keadaan ini akan diimbangi dengan perolehan kompensasi berupa gaji dan upah yang sebanding dengan tanggung jawab dan tugas yang dijalankan. Walaupun promosi sendiri sebenarnya memiliki nilai karena promosi merupakan bukti pengakuan antara lain terhadap prestasinya. Sehingga jelas dengan adanya promosi akan menambah nilai kompensasi yang diberikan dan memberikan penghargaan pengakuan prestasi yang bisa memotivasi karyawan.

Kompensasi adalah semua pendapatan yang berbentuk uang, barang langsung maupun barang tidak langsung yang diterima karyawan sebagai imbalan atau jasa yang diberikan pada perusahaan. Namun sebelum kompensasi diberikan, terlebih dahulu dilakukan proses kompensasi yaitu suatu jaringan berbagai sub proses untuk memberikan balas jasa kepada karyawan untuk pelaksanaan pekerjaan dan untuk memotivasi karyawan agar mencapai tingkat prestasi yang diinginkan (Husein Umar, 1998;16). Sistem kompensasi yang baik adalah yang mampu menjamin kepuasan para karyawan. Sehingga perusahaan akan memperoleh, memelihara serta mempekerjakan sejumlah karyawan yang dengan berbagai sikap, motivasi dan perilaku positif bekerja dengan produktif bagi kepentingan perusahan. Kompensasi yang sesuai diharapkan mampu memberikan rangsangan dan motivasi kepada tenaga kerja untuk meningkatkan prestasi kerja, serta efisiensi dan efektivitas produksi sehingga produktivitas kerja karyawan menjadi tinggi

Dalam penelitian ini akan mengkaji produktivitas kerja karyawan manufaktur di Cikarang. Perusahaan juga telah mempunyai program tahunan yang diperuntukkan demi peningkatan produktivitas kerja seluruh karyawan yang ada di Perusahaan. Salah satunya adalah program promosi jabatan yang diharapkan bisa memacu motivasi dan semangat pekerja. Selain itu, pemberian kompensasi yang ditinjau setiap tahunnya diharapkan melakukan untuk meningkatkan motivasi karyawan.

Penelitian ini bertujuan untu menganalisis secara simultan pengaruh promosi jabatan dan kompensasi terhadap motivasi karyawan serta implikasinya terhadap produktivitas kerja karyawan. Hasil penelitian ini dapat memberikan kontribusi dalam meningkatkan motivasi sehingga dapat mendorong motivasi karyawan dalam bekerja untuk mendapatkan hasil kerja yang lebih baik lagi. Hasil penelitian ini juga diharapkan dapat dijadikan bahan masukan untuk pengembangan dan pembinaan sumber daya manusia.

\section{Landasan Teori}

\subsection{Promosi Jabatan}

Salah satu dorongan seseorang bekerja pada suatu organisasi atau perusahaan adalah adanya kesempatan untuk maju. Sudah menjadi sifat dasar manusia pada umumnya untuk menjadi lebih baik, lebih maju dari posisi yang dimiliki pada saat ini. Karena itulah mereka menginginkan suatu kemajuan dalam hidupnya.

Kesempatan untuk maju didalam organisasi sering dinamakan sebagai promosi jabatan. Suatu promosi berarti perpindahan dari suatu jabatan ke jabatan lain yang mempunyai status dan tanggungjawab yang lebih tinggi. Biasanya promosi jabatan selalu disertai dengan peningkatan upah/gaji dan hak lainnya.

Promosi jabatan adalah perpindahan dari suatu jabatan ke jabatan lain yang mempunyai status dan tanggung jawab yang lebih tinggi (Martoyo, 2007:71).

56.

Jurnal Manajemen \& Bisnis Kreatif 
Sedangkan menurut Hasibuan (2008:108) promosi jabatan adalah perpindahan yang memperbesar authority dan responsibility karyawan ke jabatan yang lebih tinggi di dalam suatu organisasi sehingga kewajiban hak, status dan penghasilannya semakin besar.

Lain halnya menurut Tohardi yang dikutip dari Flippo (2002:382) bahwa promosi jabatan adalah merupakan perubahan dari pekerjaan yang satu ke yang lain yang mempunyai syarat-syarat lebih baik dalam hal kedudukan dan tanggung jawab.

Dari beberapa definisi tersebut di atas dapat disimpulkan bahwa promosi jabatan adalah kenaikan tingkat jabatan yang disertai penambahan tanggung jawab yang lebih luas yang dinilai berdasarkan prestasi karyawan dan kebutuhan perusahaan atau instansi yang diikuti dengan kenaikan kompensasi yang diberikan perusahaan atau instansi, maka promosi jabatan mempunyai arti yang penting bagi perusahaan, sebab dengan promosi berarti kestabilan perusahaan dan moral karyawan yang akan lebih terjamin. Promosi akan selalu diikuti oleh tugas, tanggung jawab yang lebih tinggi daripada jabatan yang diduduki sebelumnya. Pada umumnya promosi juga diikuti dengan peningkatan pendapatan serta fasilitas yang lain. Namun, promosi ini sendiri sebenarnya mempunyai nilai karena merupakan bukti pengakuan, antara lain terhadap prestasinya.

Karena begitu pentingnya promosi jabatan bagi perusahaan tentunya promosi jabatan harus dilihat dari beberpa dimensi atau indicator sebagai berikut:

- Pendidikan, baik latarbelakang tingkat dan bidang ilmu pengetahuannya

- Pengalaman, lama waktu bekerja atau kesesuaian bidang pekerjaannya

- Hasil kinerja yang mencakup pada insiatif dan kretifitas

- Perilaku yang mencakup pada kejujuran dan disiplin

\subsection{Kompensasi}

Kompensasi adalah semua pendapatan yang berbentuk uang, barang langsung maupun barang tidak langsung yang diterima karyawan sebagai imbalan atau jasa yang diberikan pada perusahaan. Serta kompensasi tambahan finansial atau non finansial yang diberikan berdasarkan kebijaksanaan perusahaan terhadap semua karyawan dan usaha meningkatkan kesejahteraan mereka seperti tunjangan hari raya dan uang pensiun.

Menurut pendapat yang dikemukakan oleh Thomas H. Stone seperti yang dikutip oleh Moekijat sebagai berikut:

"Compensation is any form of payment to employee for work they provide their employer."

Pendapat serupa juga dikemukakan oleh Edwin B. Flippo yang dikutip oleh Moekijat yaitu:

"Compensation given as an equitable remuniration of personal for their contribution to organization objectives"

Dari uraian diatas, dapat diambil kesimpulan bahwa kompensasi adalah imbalan jasa kepada karyawan karena karyawan tersebut telah melakukan pekerjaan sesuai dengan tugas dan tanggung jawabnya untuk mencapai tujuan perusahaan.

57.

Jurnal Manajemen \& Bisnis Kreatif 
Imbalan jasa tersebut dibagi beberapa dimensi antaralain berupa gaji, tunjangan, bonus dari keuntungan perusahaan serta fasilitas yang diberikan perusahaan.

\subsection{Motivasi}

Motivasi berasal dari kata movere yang berarti "Dorongan" atau "Menggerakkan." Secara pengertian, Motivasi berarti keadaan jiwa dan sikap mental manusia yang memberikan energi, mendorong kegiatan atau gerakan dan mengarah atau menyalurkan perilaku ke arah mencapai kebutuhan yang memberikan kepuasan atau mengurangi ketidakseimbangan. Kebutuhan-kebutuhan tersebut timbul akibat dari hubungan antar manusia yang dalam hal ini lebih ditekankan dalam proses produksi, yaitu hubungan industrial.

Motivasi Karyawan menurut Winardi (2007,p1). Motivasi merupakan hasil sejumlah proses yang bersifat internal atau eksternal bagi seorang individu, yang menyebabkan timbulnya sikap entusiasme dan persistensi dalam hal melaksanakan kegiatan-kegiatan tertentu. Sedangkan motivasi kerja adalah suatu kekuatan potensial yang ada dalam diri seorang manusia, yang dapat dikembangkannya sendiri atau dikembangkan oleh sejumlah kekuatan luar yang pada intinya berkisar sekitar imbalan moneter dan nonmoneter, yang dapat mempengaruhi hasil kinerjanya secara positif atau secara negatif, hal mana tergantung pada situasi dan kondisi yang dihadapi orang yang bersangkutan.

Menurut Malayu S.P Hasibuan (2005:143). Motivasi adalah pemberian daya penggerak yang menciptakan kegairahan kerja seseorang agar mereka mau bekerja sama, bekerja efektif dan terintegrasi dengan segala daya upayanya untuk mencapai kepuasan.

Menurut T.Hani Handoko (2003:252). Motivasi adalah keadaan dalam pribadi seseorang yang mendorong keinginan individu untuk melakukan kegiatan-kegiatan tertentu guna mencapai tujuan.

Menurut Marhot Tua Efenddi Hariandja (2002:321). Motivasi adalah faktorfaktor yang mengarahkan dan mendorong perilaku atau keinginan seseorang.

Menurut Soemanto secara umum mendefinisikan motivasi sebagai suatu perubahan tenaga yang ditandai oleh dorongan efektif dan reaksi- reaksi pencapaian tujuan. Karena kelakuan manusia itu selalu bertujuan, kita dapat menyimpulkan bahwa perubahan tenaga yang memberi kekuatan bagi tingkahlaku mencapai tujuan,telah terjadi di dalam diri seseorang.

Menurut As'ad (2002,p45) motivasi kerja didefinisikan sebagai sesuatu yang menimbulkan semangat atau dorongan kerja. Oleh sebab itu, motivasi biasa disebut sebagai pendorong atau semangat kerja. Sedangkan menurut Robbins (2002,p166), motivasi didefinisikan sebagai kesediaan untuk mengeluarkan tingkat upaya yang tinggi untuk tujuan-tujuan organisasi yang dikondisikan oleh kemampuan upaya itu untuk memenuhi sesuatu kebutuhan individu. Sementara motivasi umum bersangkutan sengan upaya ke arah setiap tujuan yang fokusnya dipersempit terhadap tujuan organisasi. Ketiga unsur kunci dalam definisi ini adalah upaya, tujuan, dan kebutuhan.

Menurut Liang Gie dalam bukunya Martoyo (2000), motivasi kerja adalah suatu dorongan yang menjadi pangkal seseorang melakukan sesuatu atau bekerja. Seseorang yang sangat termotivasi, yaitu orang yang melaksanakan upaya substansial,

58.

Jurnal Manajemen \& Bisnis Kreatif 
guna menunjang tujuan-tujuan produksi kesatuan kerjanya, dan organisasi dimana ia bekerja. Seseorang yang tidak termotivasi, hanya memberikan upaya minimum dalam hal bekerja. Konsep motivasi, merupakan sebuah konsep penting studi tentang kinerja individual.

Dari pengertian-pengertian motivasi diatas maka dapat disimpulkan bahwa motivasi merupakan suatu keadaan atau kondisi yang mendorong, merangsang atau menggerakkan seseorang untuk melakukan sesuatu sehingga ia mendapatkan apa yang menjadi tujuannya.

Para pekerja pada umumnya akan termotivasi untuk bekerja bila menghadapi kondisi-kondisi seperti :

1. Merasa diperlukan dalam organisasi.

2. Mengetahui yang diharapkan oleh organisasi.

3. Peluang untuk berkembang.

4. Tantangan yang menarik.

5. Suasana kerja yang menyenangkan.

6. Perlakuan yang adil dalam pemberian imbalan.

\subsection{Produktivitas Kerja}

Produktivitas berasal dari kata "Produktiv" yang berarti "mengandung potensi." Sehingga secara pengertian, kita dapat mengartikan bahwa produktivitas adalah proses kegiatan yang terstruktur guna menggali potensi yang ada dalam sebuah komoditi/objek. Filosofi produktivitas sebenarnya mengandung arti keinginan dan usaha dari setiap individu atau kelompok untuk selalu meningkatkan kehidupan maupun penghidupannya. Produktivitas dapat dirumuskan sebagai perbandingan antara keluaran (Output) dengan pemasukannya (Input). Semakin dekat selisih antara Output pekerjaan yang dihasilkan dengan Input yang diberikan, maka akan semakin efisien pula produktivitas sebuah pekerjaan.

Berikut pengertian produktivitas menurut para ahli, Pengertian Produktivitas Kerja menurut Basu Swastha dan Ibnu Sukotjo (1995:281) ,"produktivitas adalah sebuah konsep yang menggambarkan hubungan antara hasil (jumlah barang dan jasa) dengan sumber (jumlah tenaga kerja, modal, tanah, energi, dan sebagainya) yang dipakai untuk menghasilkan hasil tersebut." Sedangkan George J. Washinis (Rusli Syarif,1991:1) memberi pendapat bahwa "Produktivitas mencakup dua konsep dasar yaitu daya guna dan hasil guna. Daya guna menggambarkan tingkat sumber-sumber manusia, dana, dan alam yang diperlukan untuk mengusahakan hasil tertentu, sedangkan hasil guna menggambarkan akibat dan kualitas dari hasil yang diusahakan."

Menurut profesor Luis Sabourin (Rusli Syarif,1991:1) produktivitas kerja adalah "Rumusan tradisional dari produktivitas total tidak lain adalah ratio dari apa yang dihasilkan terhadap saluran apa yang digunakan untuk memperoleh hasil tersebut." Menurut Mukiyat (1998:481) bahwa,"produktivitas kerja biasanya dinyatakan dengan suatu imbangan dari hasil kerja rata-rata dalam hubungannya dengan jam kerja rata-rata dari yang diberikan dengan proses tersebut."

Sedangkan konsep produktivitas menurut piagam OSLA tahun 1984 adalah (J. Ravianto,1986:18) :

59.

Jurnal Manajemen \& Bisnis Kreatif 
1. Produktivitas adalah konsep universal, dimaksudkan untuk menyediakan semakin banyak barang dan jasa untuk semakin banyak orang dengan menggunakan sedikit sumber daya.

2. Produktivitas berdasarkan atas pendekatan multidisiplinyang secara efektif merumuskan tujuan rencana pembangunan dan pelaksanaan cara-cara produktif dengan menggunakan sumber daya secara efektif dan efisien namun tetap menjaga kualitas.

3. Produktivitas terpadu menggunakan keterampilan modal, teknologi manajemen, informasi, energi, dan sumber daya lainnya untuk mutu kehidupan yang mantap bagi manusia melalui konsep produktivitas secara menyeluruh.

4. Produktivitas berbeda di masing-masing negara denga kondisi, potensi, dan kekurangan serta harapan yang dimiliki oleh negara yang bersangkutan dalam jangka panjang dan pendek, namun masing-masing negara mempunyai kesamaan dalam pelaksanaan pendidikan dan komunikasi.

5. Produktivitas lebih dari sekedar ilmu teknologi dan teknik manajemen akan tetapi juga mengandung filosofi dan sikap mendasar pada motivasi yang kuat untuk terus menerus berusaha mencapai mutu kehidupan yang baik.

Menurut Komarudin(1992:121)," Produktivitas pada hakekatnya meliputi sikap yang senantiasa mempunyai pandangan bahwa metode kerja hari ini harus lebih baik dari metode kerja kemarin dan hasil yang dapat diraih esok harus lebih banyak atau lebih bermutu daripada hasil yang diraih hari ini."

Menurut Sondang P Siagian(1982:15),"Produktivitas kerja adalah kemampuan memperoleh manfaat sebesar-besarnya dari sarana dan prasarana yang tersedia dengan menghasilkan output yang optimal, kalau mungkin yang maksimal."

Menurut Handari Nawawi dan Kartini Handari, (1990:97-98). Menjelaskan secara konkrit konsep produktivitas kerja sebagai berikut:

1. Produktivitas kerja merupakan perbandingan terbaik antara hasil yang diperoleh dengan jumlah kerja yang dikeluarkan. Produktivitas kerja dikatakan tinggi jika hasil yang diperoleh lebih besar dari pada sumber tenaga kerja yang dipergunakan dan sebaliknya.

2. Produktivitas yang diukur dari daya guna (efisiensi penggunaan personal sebagai tenaga kerja). Produktivitas ini digambarkan dari ketepatan penggunaan metode atau cara kerja dan alat yang tersedia, sehingga volume dan beban kerja dapat diselesaikan sesuai dengan waktu yang tersedia. Hasil yang diperoleh bersifat non material yang tidak dapat dinilai dengan uang, sehingga produktivitas hanya digambarkan melalui efisiensi personal dalam pelaksanaan tugas-tugas pokoknya.

Dari pengertian diatas, dapat ditarik kesimpulan bahwa produktivitas kerja berkaitan erat dengan efisiensi dan efektivitas kerja, Produktivitas adalah rasio antara input yang diberikan kepada perusahaan terhadap output yang akan dihasilkan. Semakin input mendekati output, maka semakin efisien pula sistem tersebut. Input dalam sebuah perusahaan bisa berupa tenaga kerja, modal, material dan lain-lain. Namun aspek tenaga kerjalah yang memegang peranan terpenting dalam menentukan sebuah output sistem. Produktivitas kerja bisa dinilai dari beberpa indikator yaitu kuantitas kerja, kuantitas kerja, kehandalan serta sikap karyawan.

60. 


\subsection{Kerangka Pemikiran}

\subsubsection{Pengaruh Promosi Jabatan terhadap Motivasi}

Menurut Wahjosumidjo(1994) dalam buku Hasibuan (2015:12), ada tujuh faktor yang mempengaruhi Motivasi. Salah satu faktor motivasi itu adalah promosi jabatan. Dengan pemberian Promosi Jabatan, diharapkan seorang karyawan dapat termotivasi dalam bekerja.

\subsubsection{Pengaruh Kompensasi terhadap Motivasi}

Menurut Hasibuan (2015:29), Kompensasi baik yang berbentuk finansial maupun nonfinansial merupakan motivasi yang harus diberikan kepada para karyawan atas jasa-jasanya pada organisasi. Diharapkan dengan pemberian kompensasi mampu memberikan dorongan/motivasi para karyawan untuk bekerja lebih baik lagi.

\subsubsection{Pengaruh Motivasi terhadap Produktivitas Kerja}

Menurut Hasibuan (2015:37) salah satu faktor yang mempengaruhi produktivitas karyawan adalah motivasi. Karyawan yang memiliki motivasi kerja yang tinggi memiliki kecenderungan untuk memberikan hasil produktivitas yang lebih tinggi dari pada karyawan yang tidak termotivasi dalam mengerjakan pekerjaannya.

\subsubsection{Pengaruh Promosi Jabatan terhadap produktivitas Kerja}

Menurut Henry Simamora (1999:587) salah satu manfaat dari promosi jabatan adalh memungkinkan perusahaan untuk mendayagunakan keahlian dan kemampuan karyawan setinggi mungkin. Dengan meningkanya kemampuan karyawan diharapkan dapat meningkatkan produktivitas kerja suatu perusahaan.

\subsubsection{Pengaruh Kompensasi terhadap Produktivitas Kerja}

Kompensasi adalah berbagai macam jenis benefit yang diterima oleh seeorang karyawan baik secara finansial maupun non finansial. Peberiaan kompensasi adalah salah satu cara untuk mendongkrak produktivitas kerja dari seorang karyawan. Menurut Hasibuan (2015:144) kompensasi adalah salah satu faktor yang mempengaruhi produktivitas kerja, sebab dengan pemberian kompensasi karyawan terdorong untuk bekerja lebih giat lagi.

\section{Metode Penelitian}

Penelitian ini menggunakan penelitian deskriptif dengan pendekatan kuantitatif yaitu mengungkapkan pengaruh antar variabel dan dinyatakan dalam angka serta menjelaskannya dengan membandingkan dengan teori-teori yang telah ada dan menggunakan teknik analisis data yang sesuai dengan variabel dalam penelitian. Variabel yang diteliti yaitu Promosi jabatan dan Kompensasi sebagai variabel independen/bebas (x), variabel motivasi sebagai variabel penghubung (y) dan variabel produktivitas kerja sebagai variabel dependen/terikat (z). Metode pengumpulan data menggunakan metode survey. Singarimbun (2011:3) menjelaskan bahwa penelitian dengan metode survey ini merupakan penelitian yang mengambil sampel dari suatu populasi dan menggunakan kuesioner sebagai alat pengumpulan data yang pokok. Kuesioner adalah alat pengumpul data yang dilakukan dengan cara

61. 
memberi seperangkat pertanyaan atau pernyataan tertulis kepada responden untuk dijawabnya.

\subsection{Populasi dan Sample}

Menurut Sugiyono (2013:80) populasi adalah wilayah generalisasi yang terdiri atas obyek/subyek yang mempunyai kualitas dan karakteristik tertentu yang ditetapkan oleh peneliti untuk dipelajari dan kemudian ditarik kesimpulannya. Jadi populasi bukan hanya orang, tetapi juga obyek dan benda-benda alam yang lain. Hal ini sejalan dengan pendapat Emory dalam Assegaf (2009) yang menyatakan populasi merupakan sekumpulan elemen yang dapat digunakan untuk beberapa kesimpulan. Dengan demikian populasi dalam penelitian ini adalah seluruh karyawan berjumlah 120 orang

Menurut Sugiyono (2012:81), sampel adalah bagian dari jumlah dan karakteristik yang dimiliki oleh populasi tersebut. Selanjutnya Sugiyono (2012:86) memaparkan bahwa jumlah sampel yang diharapkan 100\% mewakili populasi adalah sama dengan jumlah anggota populasi populasi itu sendiri. Roscoe dalam Sugiyono (2012:90) menyatakan bahwa ukuran sampel yang layak dalam penelitian adalah antara 30 sampai dengan 500.

Sampel pada penelitian ini adalah seluruh populasi yang menjadi obyek penelitian yaitu semua karyawan berjumlah 120 orang.

\subsection{Teknik Pengumpulan Data}

Dalam pengumpulan data ini, peneliti melaksanakan riset secara langsung pada objek penelitian untuk mendapatkan data yang diperlukan guna melengkapi data yang dibutuhkan yaitu dengan cara :

1. Angket (Questionnaire). Angket adalah teknik pengumpulan data dengan cara mengajukan pertanyaan tertulis untuk dijawab secara tertulis pula oleh responden. Tujuan dari penyebaran angket adalah untuk mencari informasi lengkap mengenai suatu masalah. Peneliti mendapatkan data untuk penelitian dari angket ini.

2. Wawancara (Interview). Yaitu sebuah metode pengumpulan data dengan bertanya langsung kepada responden.

3. Studi Pustaka. Yaitu sebuah metode pengumpulan informasi dengan cara mempelajari literatur yang berkaitan dengan penelitian ini.

\subsection{Rancangan Analisis dan Uji Hipotesis}

\subsubsection{Rancangan Analisis}

Analisa Statistik Deskriptif yaitu suatu metode pengumpulan data untuk memperoleh bahan-bahan teoritis yang dapat dijadikan dasar bagi pengkajian masalah. Melalui penelitian ini, Penulis mempelajari buku-buku dan lainnya yang ada hubungannya dengan masalah yang dibahas baik secara langsung maupun tidak langsung. Teknik deskriptif memberikan informasi mengenai data yang dimiliki dan tidak bermaksud menguji hipotesa. Terdapat empat jenis skala yang dapat digunakan

62. 
mengukur atribut, yaitu skala nominal, skala ordinal, skala interval dan skala ratio. Adapun langkah-langkahnya adalah sebagai berikut :

a. Analisis Tabulasi Frekwensi

b. Analisis Rentang Skala

\subsubsection{Uji Hipotesis}

Berdasarkan permasalahan-permasalahan ada, maka Penulis mencoba membuat hipotesis yang masih perlu diuji kebenarannya.

Hipotesis 1 : Terdapat pengaruh promosi jabatan terhadap motivasi

Hipotesis 2 : Terdapat pengaruh kompensasi terhadap motivasi

Hipotesis 3 : Terdapat pengaruh promosi jabatan dan kompensasi secara simultan terhadap motivasi

Hipotesis 4 : Terdapat pengaruh promosi jabatan terhadap produktivitas kerja

Hipotesis 5 : Terdapat pengaruh kompensasi terhadap produktivitas kerja

Hipotesis 6 : Terdapat pengaruh motivasi terhadap produktivitas kerja

ipotesis 7 : Terdapat pengaruh promosi jabatan, kompensasi dan motivasi secara simultan terhadap produktivitas kerja

\section{Hasil Penelitian dan Pembahasan}

4.1 Pengujian Instrumen

\section{Uji Validitas}

Dari hasil pengujian data dengan menggunakan program SPSS pada semua variabel penelitian semua indikator yang tertuang dalam sebuah pernyataan pada kuesioner dinyatakan valid karena nilai validitas $>0,3$.

\section{Uji Realibilitas}

Berdasarkan hasil pengujian dapat disimpulkan bahwa semua variabel yang digunakan dalam penelitian ini adalah reliabel, karena memiliki nilai Cronbach Alpha ( $\alpha$ lebih besar dari 0,60. Sesuai yang disyaratkan oleh Ghozali (2005:42) bahwa suatu konstruk dikatakan reliabel jika nilai Cronbach Alpha> 0,60.

\section{Uji Normalitas}

Uji normalitas digunakan untuk mengetahui apakah populasi data berdistribusi normal atau tidak (Priyatno, 2008:28).Normalitas data merupakan syarat yang harus dipenuhi oleh suatu sebaran data sebelum melakukan analisis regresi.Hal ini bertujuan untuk menghasilkan model regresi yang baik.Model regresi yang baik adalah data yang berdistribusi normal atau mendekati normal (Santoso, 2004:212).Uji normalitas yang dilakukan terhadap sampel denganmenggunakan Kolmogorov-Smirnov Test dengan menetapkan tingkat signifikansi $(\alpha)$ sebesar $5 \%$.

Uji ini dilakukan pada saat variabel dengan ketentuan bahwa jika secara individual masing-masing variabel memenuhi asumsi normalitas, maka secara simultan variabelvariabel tersebut juga bisa dinyatakan memenuhi asumsi normalitas. Kriteria pengujian dengan melihat besaran Kolmogorov-Smirnov Test adalah sebagai berikut :

a. Jika signifikansi $>0,05$ maka, data tersebut berdistribusi normal

b. Jika signifikansi $<0,05$ maka, data tersebut tidak berdistribusi normal

\section{Tabel Uji Normalitas Data}

63. 


\begin{tabular}{|l|l|l|l|l|}
\hline \multirow{2}{*}{ NO } & \multirow{2}{*}{ VARIABEL } & $\begin{array}{l}\text { Kolomogrov- } \\
\text { Smirnova }^{\mathbf{a}}\end{array}$ & \multirow{2}{*}{ Kesimpulan } \\
\cline { 3 - 3 } & $\begin{array}{l}\text { Test } \\
\text { Statistic }\end{array}$ & $\mathbf{A}$ & \\
\hline 1 & Promosi Jabatan $\left(\mathrm{X}_{1}\right)$ & 0,094 & & Dist. Normal \\
\hline 2 & Komensasi $\left(\mathrm{X}_{2}\right)$ & 0,065 & \multirow{2}{*}{0,05} & Dist. Normal \\
\hline 3 & Motivasi $(\mathrm{Y})$ & 0,084 & & Dist. Normal \\
\hline 4 & Produktivitas Kerja $(\mathrm{Z})$ & 0,111 & & Dist. Normal \\
\hline
\end{tabular}

Sumber : Data Hasil Pengolahan SPSS

Dari tabel di atas terlihat bahwa semua indikator pada variabel kinerja berdistribusi normal karena nilai Kolmogorov-Smirnov > 0,05.

\subsection{Pembahasan Deskriptif}

Berdasarkan hasil analisa terhadap tanggapan - tanggapan responden terkait dengan fenomena - fenomena yang terjadi, maka diperlukan pembahasan deskriptif sebagai berikut :

1. Promosi jabatan ( $\left.\mathbf{X}_{\mathbf{1}}\right)$ secara keseluruhan memiliki kriteria cukup setuju, artinya sistem promosi jabatan yang dilakukan untuk posisi tersebut mendapat tanggapan kurang positif terlihat dari satu indikator mendapat tanggapan tidak setuju dan empat indikator mendapat tanggapan kurang setuju antaralain :

A. Prosedur promosi jabatan pada posisi ini dianggap tidak memperhatikan tingkat pendidikan hal tersebut disebabkan oleh perluasan kapasitas produksi yang cukup cepat yang tidak mampu dimbangi dengan penyediaan dan pengembangan sumber daya manusia, sehingga dalam menutupi kekurangannya memposisikan SDM yang tersedia secara singkat dari posisi dibawahnya untuk dipromosikan.

B. Kesesuaian penempatan jabatan dengan latar belakang pendidikan dan Kesesuaian jabatan dengan kemampuan atau kompetensi karyawan, mendapat tanggapan kurang positif kedua hal tersebut disebabkan oleh sistem penilaian matrik kompetensi karyawan yang belum diterapkan secara konsisten dan belum secara keseluruhan sehingga kekurangan data tertulis mengenai kompetensi masing masing karyawan dan ini mengakibatkan subjektifitas penilaian pada saat promosi lebih dominan. Walaupun sekarang sudah disiasati dengan penerapan assesment pada saat promosi dengan assesor dari lintas departemen.

C. Perusahaan menetapkan promosi berdasarkan pengalaman karyawan hal ini mendapat tanggapan kurang positif karena yang dianggap pengalaman oleh karyawan umumnya adalah lama waktu bekerja diperusahaan, sehingga apabila pengembangan skill dan kompetensinya kurang tidak ada jaminan lama waktu bekerja mendapatkan prioritas dalam promosi. Hal ini tidak terlepas dari peran HRD dan Pimpinan menyusun dan melaksanakan rencana pengembangan karyawannya.

D. Inisiatif dan kreatifitas serta ketepatan waktu masuk kerja sebagai faktor penialaian dalam promosi mendapat tanggapan positif, hal ini lebih ke sistem

64. 
pengukuran yang lebih mudah dan sudah bisa diukur sehingga data inisiatif dan kreatifitas bisa diukur dengan jumlah dan kualitas proyek improvemen pada masing masing karyawan begitupun dengan sub variabel kedisiplinan ketepatan waktu masuk kerja sudah terukur dari data absensi karyawan.

2. Kompensasi $\left(\mathbf{X}_{2}\right)$ yang diperoleh karyawan masuk kedalam kriteria tidak setuju atau mendapat respon negatif dengan beberapa indikator yang ditanggapi tidak setuju antara lain :

A. Kesesuaian gaji dan tunjangan dengan beban kerja dianggap tidak sesuai, hal ini disebabkan kesesuaian struktur grade karyawan dengan jabatan belum terstruktur dengan baik, masih ada irisan grade yang cukup lebar diantara jabatan sehingga masih ada besaran gaji yang tumpang tindih antara atasan dengan bawahan terutama pada kedua posisi ini.

B. Adapun pemberian bonus masih dianggap oleh karyawan tidak diberikan sesuai dengan prestasi kerja, pada kenyataannya bonus diberikan sesuai dengan hasil penilaian kinierja karyawan yang dinilai atasan setiap tahun, namun karyawan masih merasa pemberian bonus belum sesuai dengan prestasi kerjanya sehingga dianggap tidak adil. Hal ini disebabkan sistem penilaian kinerja yang ada kurang obyekif, kurang bisa dibuktikan dalam bentuk hasil yang terukur terutama dari hasil kerja sehingga penilaian secara subyektif terkadang terjadi.

C. Fasilitas ditanggapi kurang menunjang pelaksanaan kelancaran bekerja, ini disebabkan area yang cukup luas dalam area produksi dimana lay out fasilitas penunjang masih cukup jauh seperti toilet yang ada di area produksi perlu direlokasi supaya jaraknya tidak terlalu jauh, ruang untuk tempat air minum perlu diperbanyak sehingga tidak menyebabkan kehilangan waktu cukup banyak pada saat mengguakan fasilitas tersebut. Begitupun dengan fasilitas umum untuk karyawan seperti klinik, kantin dan lainnya dalam lingkungan pabrik tersentralisasi di satu tempat tetapi tidak diiringi dengan alat transportasi yang cukup di internal pabrik sehingga membutuhkan waktu yang lama sampai ke tempat tujuan.

3. Motivasi Karyawan ( Y ) masuk kriteria cukup setuju atau cukup terlihat secara keseluruhan pertanyaan dijawab cukup setuju yang memiliki arti bahwa motivasi karyawan foreman dan junior section head produksi kurang positif terlihat dari tiga indikator dijawab tidak setuju dan sepuluh indkator lainnya dijawab cukup setuju, indikator - indikator tersebut antara lain :

A. Sub variabel motif terkait dengan indikator rasa aman dalam bekerja dan kepuasan dalam melaksanakan pekerjaan mendapat tanggapan tidak setuju atau mengandung arti tidak menjamin para karyawan dari rasa aman disebabkan kekhawatiran mengenai gangguan kesehatan yang timbul dari kondisi, tekait dengan tanggapan yang negatif mengenai kepuasan dalam melaksanakan pekerjaan disebabkan oleh banyak hal salah satu diantaranya kurang maskimalnya fasilitas penunjang dalam bekerja dan kurang intensif komunikasi atasan dan bawahan.

B. Indikator harapan mendapat tanggapan cukup setuju atau dalam katogori cukup, walaupun katagori cukup namun terlihat ada keragu-raguan mengenai harapan karyawan dari perusahaan dan hasil ini bisa diartikan tanggapan yang

65.

Jurnal Manajemen \& Bisnis Kreatif 
kurang positif yang disebabkan antara lain oleh semangat berprestasi kurang karena tidak terlihat perbedaan kompensasi pada saat promosi jabatan, kurangnya arahan dari atasan terutama arahan mengenai pengembangan diri, prestasi kerja kurang bisa diukur dengan baik terhadap individu sehingga terasa kurang penghargaan terhadap prestasi kerja.

C. Indikator insentif atau tunjangan mendapat tanggapan tidak setuju disebabkan karyawan merasa keseuaian penialain kinerja dengan kompensasi yang diberikan tidak sesuai, sehingga timbul presepsi merasa kurang adil.

4. Produktivitas Kerja ( $\mathbf{Z})$ memiliki kriteria cukup baik terlihat dari hasil data responden menyatakan cukup baik dengan pernyataan atau pertanyaan kuesioner yang diajukan, walaupun termasuk katagori cukup ini artinya kurang positif. beberapa indikator produktivitas dijawab cukup setuju bahkan satu indikator dijawab tidak baik tetapi ada beberapa indikator yang dijawab baik, hal ini bisa diliha sebagai berikut :

A. Indikator kualitas kerja direspon dengan jawaban cukup baik hal ini artinya produktivitas karyawan perusaahan manufactur di cikarang cukup baik namun terlihat ada keraguan dari responden sehingga jawaban responden ada di cukup baik yang cendrung kurang positif hal ini disebabkan oleh kompetensi karyawan yang tidak sama antar karyawan dengan bagian yang sama, keahlian dan ketelitian karyawan yang kurang disebabkan kurangnya pelatihan pada bidang teknisnya.

B. Indikator kuantitas kerja direspon sama yaitu masuk katagari cukup baik artinya meskipun katagori cukup baik namun indikasinya adalah respon kurang positif dari responden terhadap produktivitas kerja yang disebabkan kurang terawatnya kebersihan lingkungan kerja dan kurangnya disiplin dalam komitmen pemenuhan target produksi,

C. Indikator kehandalan masuk dalam katagori cukup baik ini terlihat dari kesesuaian antara intruksi kerja dengan pelaksanaan dilapangannya terkadang terkendala sehingga terjadi perbedaan antara intruksi kerja dengan pelaksaanannya.

D. Indikator sikap direspon dengan jawaban baik, ini artinya sikap karyawan terhadap pimpinan, sikap terhadap sesama kayawan dan kerjasama karyawan dengan rekan kerja dan atasannya masuk katagori baik.

\subsection{Pembahasan Verifikatif}

Berdasarkan hasil perhitungan penelitian yang teah dijelaskan sebelumnya maka dapat disajikan tentang verifikatif sebagai berikut :

\section{Pengaruh Variabel Promosi Jabatan Terhadap Motivasi}

Pada alfa 5\%, promosi jabatan berpengaruh signifikan terhadap motivasi sebesar 26,7\% dengan koefisien jalur 0,517 dan tingkat signifikansi sebesar 0,000 dimana 0,000 lebih kecil dari 0,05. Hal ini berarti promosi jabatan berpengaruh signifikan terhadap motivasi kerja karyawan manufactur di Cikarang. Hal tersebut sependapat dengan penelitian Cut Fauza Alia, Mukhlis Yunus, dan Mahdani (2015)

66. 
dalam penelitiannya menyatakan bahwa promosi jabatan berpengaruh siginifikan sebesar 5,24\% dengan signifikasi ( $\alpha$ ) 0,045.

\section{Pengaruh Variabel Kompensasi Terhadap Motivasi}

Kompensasi berpengaruh secara signifikan terhadap motivasi karyawan terlihat dari hasil signifikansi 0,164 atau 16,4\% dan tingkat signifikan sebesar 0,000. Dimana $0,000 \leq 0,05$. Hal ini berarti kompensasi berpengaruh signifikan terhadap motivasi kerja karyawan manufaktur di CIkarang. Dengan demikian penelitian ini telah membuktikan teori tentang pengaruh kompensasi terhadap motivasi seperti penelitian yang di ungkapkan oleh Tama Verizqy dan Retno Kusumastuti bahwa kompensasi memiliki pengaruh yang signifikan positif sebesar $35 \%$ dengan nila signifikasi sebesar 0,000 .

\section{Pengaruh Simultan Variabel Promosi Jabatan dan Kompensasi terhadap Motivasi}

Promosi jabatan dan kompensasi secara simultan berpengaruh terhada motivasi. Total pengaruh promsi jabatan dan kompensasi terhadap motivasi sebesar $72,5 \%$ dengan nilai sig $(0,000)<\alpha(0,05)$ dan $F_{\text {hitung }}(147,900)>F_{\text {tabel }}(3,07)$. Hal ini berarti promosi jabatan dan kompensasi mempunyai kontribusi $72,5 \%$ terhadap motivasi, sedangkan sisanya sebesar $27,5 \%$ merupakan variabel lain yang tidak diteliti. Variabel lain yang tidak diteliti dapat berupa gaya kepemimpinan, budaya organisasi, pelatihan dan pengembangan karyawan dan sebagainya. Hasil penelitian ini didukung oleh hasil penelitian Khusnul Khotimah Mochammad Al-Musadieq M. Soe'oed Hakam (2015), mengenai "pengaruh promosi jabatan dan kompensasi (insentif) terhadap motivasi kerja" yang menyatakan bahwa promosi jabatan dan kompensasi (insentif) berpegaruh signifikan dengan nilai $\mathrm{R}$ square 0,683 atau berpengaruh sebesar $68,3 \%$. Semakin tinggi $\mathrm{R}$ square makan semakin beasr kemampuan variabel independen atau eksogen tersebut dalam menjelaskan variabel devenden atau endogen sehingga semakin baik persamaan struktur yang terbentuk.

\section{Pengaruh Variabel Motivasi Terhadap Produktivitas Kerja}

Motivasi berpengaruh signifikan terhadap produktivitas kerja sebesar 22,8\% dan tingkat signifikansi sebesar 0,001 dimana 0,001 lebih kecil dari 0,05. Hal ini berarti motivasi berpengaruh signifikan terhadap produktivitas kerja karyawan perusahaan manufaktur di Cikarang. Motivasi berpengaruh positif terhadap produktivitas kerja karyawan perusahaan manufactur di Cikarang. Berarti semakin tinggi motivasi karyawan atas suatu pekerjaan maka akan semakin meningkatkan produktivitas kerjanya. Demikian juga sebaliknya, semakin rendah motivasi karyawan semakin rendah produktivitas kerja karyawannya. Menurut Mathis (2009) mengemukakan bahwa, Motivasi (motivation) adalah keinginan dalam diri seseorang yang menyebabkan orang tersebut bertindak. Orang biasanya bertindak karena satu alasan : untuk mencapai tujuan. Jadi, motivasi adalah sebuah dorongan yang diatur oleh tujuan dan jarang muncul dalam kekosongan. Kata-kata kebutuhan, keinginan, hasrat dan dorongan, semuanya serupa dengan motif, yang merupakan asal dari kata motivasi. Memahami motivasi sangatlah penting karena kinerja, reaksi terhadap kompensasi, dan persoalan SDM yang lain dipengaruhi dan memengaruhi motivasi. Motivasi terbentuk

67.

Jurnal Manajemen \& Bisnis Kreatif 
dari sikap (attitude) karyawan dalam menghadapi situasi (situation) kerja di perusahaan. Motivasi merupakan hasil sejumlah proses yang bersifat internal atau eksternal bagi seorang individu, yang menyebabkan timbulnya sikap entusiasme dan persistensi dalam hal melaksanakan kegiatan-kegiatan tertentu.

\section{Pengaruh Variabel Promosi Jabatan Terhadap Produktivitas Kerja.}

Pengaruh Variabel Promosi jabatan $\left(\mathrm{X}_{1}\right)$ secara langsung terhadap Produktivitas kerja (Z) sebesar 8\% dengan tingkat signifikasi 0,025 dimana 0,025 lebih kecil dari 0,05 hal ini berarti promosi jabatan berpengaruh signifikan terhadap produktivitas kerja secara langsung sebesar $8 \%$.

Pengaruh Variabel Promosi jabatan $\left(\mathrm{X}_{1}\right)$ secara tidak langsung terhadap produktivitas kerja $(\mathrm{Z})$ yaitu dengan melalui motivasi $(\mathrm{Y})$ adalah sebesar 51,4\% sehigga ini menjelaskan bahwa pengaruh promosi jabatan secara langsung terhadap produktivitas kerja lebih kecil pengaruhnya dibandingkan melalui pengaruh terhadap motivasi.

\section{Pengaruh Variabel Kompensasi Terhadap Produktivitas Kerja.}

Dari hipotesis pengaruh variabel kompensasi $\left(\mathrm{X}_{2}\right)$ secara langsung terhadap Produktivitas kerja $(Z)$ dihasilkan nilai sig $(0,226)$ lebih besar dari $\alpha(0,05)$ dan thitung $(-$ $1,128)$ lebih kecil dari tabel $(1,65787)$. Karena t hitung lebih kecil dari t tabel aka kompensasi secara langsung dinyatakan tidak berpengaruh dan untuk untuk tingkat signifikasinya juga tidak signifikan karena sig lebih besar dari 0,05 sehingga hal ini bisa dinyatakan bahwa kompensasi tidak berpengarus terhadap produktivitas kerja seara langsung.

Namun pengaruh variabel kompensasi $\left(\mathrm{X}_{2}\right)$ terhadap produktivitas $(\mathrm{Z})$ secara tidak langsung yaitu melalui motivasi dihasilkan nilai pengaruh sebesar $5 \%$ sehingga kalau dibandingkan maka variabel kompensasi $\left(\mathrm{X}_{2}\right)$ akan berpengaruh terhadap produktivitas (Z) jika melalui perantara motivasi (Y) sebesar 5\%.

\section{Pengaruh simultan variabel promosi jabatan $\left(\mathrm{X}_{1}\right)$, kompensasi $\left(\mathrm{X}_{2}\right)$ dan Motivasi (Y) terhadap Produktivitas kerja (Z).}

Berdasarkan perhitungan angka signifikan sebesar $0.000<0,05$, dan $\mathrm{F}$ hitung $(23,810)>\mathrm{F}_{\text {tabel }}(2,69)$, maka $\mathrm{H} 0$ ditolak dan $\mathrm{H} 1$ diterima, artinya terdapat pengaruh signifikan secara simultan dari variabel promosi jabatan $\left(\mathrm{X}_{1}\right)$, kompensasi $\left(\mathrm{X}_{2}\right)$ dan motivasi (Y) terhadap produktivitas kerja (Z). Besarnya angka R Square (r2) adalah 0.381 atau Koefisien Determinasi sebesar $38,1 \%$ yang artinya bahwa pengaruh promosi jabatan $\left(\mathrm{X}_{1}\right)$, kompensasi $\left(\mathrm{X}_{2}\right)$ dan motivasi $(\mathrm{Y})$ terhadap kinerja karyawan $(\mathrm{Z})$ secara simultan adalah 38,1\% sedangkan 61,9\% disebabkan oleh variabel-variabel lain di luar model.

\section{Simpulan dan Saran \\ 5.1 Kesimpulan}

Penelitian dan pembahasan yang telah dilakukan mengenai pengaruh promosi jabatan dan kompensasi terhadap motivasi serta implikasinya terhadap produktivitas

68.

Jurnal Manajemen \& Bisnis Kreatif 
kerja karyawan perusahaan manufaktur di Cikarang, maka penulis dapat sampaikan kesimpulan sebagai berikut :

1. Promosi jabatan merupakan salah satu bentuk penghargaan yang diberikan oleh perusahaan untuk karyawan yang berprestasi sehingga memotivasi kinerja jadi lebih baik dan juga merupakan salah satu cara untuk pemenuhan posisi-posisi kosong sebagai pengganti atau regenerasi karyawan. Promosi jabatan ini akan menarik minat apabila hal ini dilakukan sesuai dengan prosedur dan dilakukan secara obyektif dan transfaran dengan dasar pertimbangan prestasi kerja, pendidikan kemampuan serta persyaratan lainnya sebagai penunjang promosi jabatan apabila hal ini tidak terpenuhi maka promosi jabatan akan kurang diminati karyawan. Hal ini terlihat dari skor total penialaian terhadap promosi jabatan berada diinterval cukup setuju dengan nilai skor sebesar 2.656 dan rata -rata skor sebesar 379,43 namun tampak respon kurang positif adalah adanya keragu-raguan mengenai pelaksanaan promosi jabatan dan hasil penilaian promosi jabatan dilakukan kurang sesuai dengan persyaratan promosi jabatan baik itu dari syarat tingkat pendidikan maupun dari kompetensi atau kemampuan.

2. Kompensasi atau balas jasa harus ditetapkan atas asas adil dan layak serta dengan memperhatikan undang-undang perburuhan yang berlaku, prinsip adil dan layak ini harus mendaptkan perhatian dengan sebaik baiknya supaya balas jasa yang diberikan merangsang gairah motivasi dan kepuasan kerja karyawan. Pemberian kompensasi di perusahaan sudah sesuai dan mengikuti undang - undang perburuhan yang berlaku namun tanggapan asas keadilan mendapat respon kurang positif dimana karyawan khusunya posisi foreman dan junior section head produksi merasa asas adilnya tidak terpenuhi yaitu merasa kompensasi yang diberikan tidak sebanding dengan beban kerja yang dibebankan, walaupun skor penilaian kompensasi secara total berada di interval cukup setuju yaitu sebesar 2.483 dan rata-rata skor sebesar 310,375 namun empat indikator yang menunjukan asas keadilan mendapat respon tidak setuju antaralain kesesuaian gaji dan tunjangan dengan beban kerja, pemberian bonus secara adil serta fasilitas kerja yang disediakan tidak menunjang kelancaran dalam bekerja.

3. Motivasi kerja adalah suatu dorongan yang menjadi pangkal seseorang melakukan sesuatu atau bekerja. Seseorang yang sangat termotivasi, yaitu orang yang melaksanakan upaya substansial, guna menunjang tujuan-tujuan produksi kesatuan kerjanya, dan organisasi dimana ia bekerja. Seseorang yang tidak termotivasi, hanya memberikan upaya minimum dalam hal bekerja. Motivasi karyawan masuk dalam katagori cukup terlihat dari skor total penilaian tanggapan karyawan terhadap motivasi karyawan berada pada interval cukup setuju atau cukup termotivasi namun keraguan lagi muncul dengan skor penilaian hanya berada di interval cukup dengan total skor sebesar 4.467 dan rata-rata skor sebesar 343,62. Keraguan tersebut disebabkan oleh kurangnya motif bekerja karena merasa tidak aman dalam bekerja baik aman secara ekonomi maupun secara fisik, begitupun dengan harapan yang kurang terhadap perusahaan yang disebabkan proses promosi dan kompensasi yang diberikan tidak menarik karyawan untuk termotivasi kinerjanya.

69.

Jurnal Manajemen \& Bisnis Kreatif 
4. Produktivitas ini digambarkan dari ketepatan penggunaan metode atau cara kerja dan alat yang tersedia, sehingga volume dan beban kerja dapat diselesaikan sesuai dengan waktu yang tersedia dan target yang ditetapkan. Indikator produktivitas kerja terdiri dari kualitas, kuantitas kehandalan serta sikap kerja karyawan itu sendiri. Produktivitas kerja karyawan secara total masuk dalam katagori cukup baik dengan skor sebesar 4933 dan rata-rata skor sebesar 379,46 namun selain indikator sikap yang masuk katagori baik indikator lainnya mendapat respon kurang positif yaitu indikator kuantitas, kualitas dan kehandalan masuk katagori cukup baik sedangkan untuk indikator kualitas ada parameter yang dinyatakan tidak baik yaitu tingkat kebersihan lingkungan kerja.

5. Promosi jabatan berpengaruh signifikan terhadap motivasi dengan koefisien jalur sebesar 0,517 atau sebesar 26,7\%. Sedangkan kompensasi berpengaruh signifikan terhadap motivasi dengan koefisien jalur 0,405 atau sebesar 16,4 \%. Dari hasil yang diperoleh menunjukan bahwa promosi jabatan lebih dominan memberikan kontribusi terhadap motivasi karyawan dibandingkan kompensasi $(0,517>0,405)$.

6. Nilai koefisien determinan pengaruh simultan promosi jabatan dan kompensasi terhadap motivasi sebesar 0,725 . Sehingga dapat diartikan bahwa total pegaruh promosi jabatan dan kompensasi terhadap motivasi sebesar 0,725 atau sebesar $72,5 \%$. Berdasarkan hasil penelitian ini menunjukan bahwa promosi jabatan dan kompensasi memiliki kontribusi terhadap motivasi sebesar 72,5 \% sedangkan sisanya 0,275 atau sebesar $27,5 \%$ merupakan pengaruh kontribusi variabel lain yang tidak diteliti.

7. Promosi jabatan berpengaruh secara langsung signifikan terhadap produktivitas kerja dengan koefisien jalur sebesar 0,283 atau sebesar $8 \%$ dan promosi jabatan memiliki nilai pengaruh yang lebih besar terhadap produktivitas kerja jika melalui motivasi yaitu sebesar $51,4 \%$.

8. Variabel kompensasi tidak berpengaruh secara langsung terhadap produktivitas kerja terbukti dengan nilai signifikasi $(0,226)$ lebih besar dari $\alpha(0,05)$ dan $t_{\text {hitung }}(-$ $1,128)$ lebih kecil dari $t_{\text {tabel }}(1,65787)$. Kompensasi berpengaruh positif terhadap produktivitas kerja apabila melalui perantara variabel motivasi yaitu pengaruhnya sebesar $5 \%$.

9. Nilai koefisisen jalur pengaruh motivasi terhadap produktivitas kerja sebesar 0,477 . Sehingga dapat diartikan bahwa pengaruh motivasi terhadap produktvitas kerja sebesar 0,228 atau sebesar 22,8\%. Berdasarkan hasil penelitian ini menunjukan bahwa motivasi memiliki kontribusi terhadap produktivitas kerja sebesar 22,8\% .

10. Nilai koefisien determinan pengaruh simultan promosi jabatan, kompensasi dan motivasi terhadap produktivitas kerja sebesar 0,381. Sehingga dapat diartikan bahwa total pegaruh promosi jabatan, kompensasi dan motivasi terhadap produktivitas kerja sebesar 0,381 atau sebesar 38,1\%. Berdasarkan hasil penelitian ini menunjukan bahwa promosi jabatan, kompensasi dan motivasi memiliki kontribusi terhadap produktivitas kerja sebesar 38,1 \% sedangkan sisanya 0,619 atau sebesar $61,9 \%$ merupakan pengaruh kontribusi variabel lain yang tidak diteliti.

70.

Jurnal Manajemen \& Bisnis Kreatif 


\subsection{Saran-saran}

Berdasarkan hasil pembahasan dan kesimpulan penelitian ini, maka disarankan hal-hal sebagai berikut :

1. Pihak manajemen diharapkan melakukan evaluasi terkait dengan pelaksanaan promosi jabatan sehingga tidak ada keraguan dari karyawan untuk mengikutinya. Adapun langkah yang perlu ditempuh antara lain membuat rancangan sistim promosi dari kedua tahap proses promosi jabatan yaitu mulai dari transfaransi persyaratan yang harus dipenuhi untuk menempati posisi yang ditawarkan dan melalui tahapan seleksi yang cukup transfaran, serta dari sisi kompensasi yang akan diberikan untuk posisi jabatan yang dipromosikan jelas dan tersosialisasikan. Sehingga kedua hal tadi akan menumbuhkan semangat berprestasi dengan kompensasi yang tidak menimbulkan keraguan bagi karyawan.

2. Pihak manajemen diharapkan dapat menumbuhkan asas keadilan dalam pemberian kompensasi dengan cara melakukan job value terhadap posisi dan beban kerja masing masing bagian sehingga kompensasi yang diberkan bisa disesuaikan dengan beban kerjanya, restrukturisasi jumlah grade dalam satu posisi jabatan disesuaikan dengan posisi jabatan sehingga tumpang tindih garde antar level jabatan yang berbeda tidak terlalu lebar, perubahan sistim penilaian kinerja individu yang lebih detil dan terukur terhadap hasil kerja seperti dibuatkan individual score card sehingga penilaian kinerja bisa lebih obyektif. Penambahan fasilitas kerja terutama di area produksi seperti perubahan posisi toilet yang lebih dekat ke area produksi, penambahan sarana transportasi di dalam lingkungan pabrik berupa sepeda, disediakan lokasi relaksasi sesaat di area produksi bisa berupa coffee corner atau sejenisnya untuk menghilangkan kejenuhan dalam bekerja.

3. Perusahaan sebaiknya memberikan program-program yang menumbuhkan motif dan harapan karyawan jadi lebih baik diantaranya memberikan waktu rekreasi bersama secara terjadwal setiap tahun dengan tepat sehingga menumbuhkan kepercayaan dan harapan karyawan terhadap perusahaan, diadakan copy morning yaitu komunikasi antara atasan dan bawahan diluar pekerjaan sehingga menimbulakan kedekatan yang bisa membangun kepercayaan antara atasan dan bawahan, program persiapan pensiun satu atau dua tahun sebelum masa pensiun sehingga memberikan harapan bagi karyawan untuk bekerja lebih lama dengan perusahaan dan memberikan jaminan keamanan secara ekonomi.

4. Pihak manajemen sebaiknya meningkatkan kebersihan lingkungan kerja, dengan melakukan program TPM ( Total Productive Maintenance ) atau minimal 5R secara konsisten, sehingga bisa menumbuhkan tingkat kepedulian karyawan terhadap lingkunga kerja dan terhadap fasilitas kerja seperti mesin , tooling dan sarana prasarana lainnya. Selain kebersihan program TPM yang dilakukan secara konsisten bisa mengurangi tingkat resiko kerusakan mesin atau sarana kerja sehingga menambah kenyamanan para operator dalam bekerja yang pada akhirnya akan menambah produktivitas kerja.

71. Jurnal Manajemen \& Bisnis Kreatif 


\section{Daftar Refernsi}

Hasibuan, S.P Malayu. 2016. Manajemen Sumber Daya Manusia. Edisi Revisi, Jakarta : Bumi Aksara.

Mangkunegara, Prabu Anwar. 2016. Manajemen SDM Perusahaan. Bandung : Remaja Rosdakarya Offset.

Dessler, Gary. 2010. Manajemen Sumber Daya Manusia. Edisi Kesepuluh Jilid 1, Jakarta : PT Indeks.

Noe, Raymond A. Hollenbeck, John R. Gerhart, Barry \& Wright, Patrick M. 2014. Manajemen Sumber Daya Manusia : Mencapai Keungulan Bersaing. Edisi 6, Jakarta : Salemba Empat.

Sugiyono, 2014. Metode Penelitian Manajemen. Cetakan ke-3, Bandung : CV Alfabeta.

Sunyoto, Danang. 2015. Penelitian Sumber Daya Manusia. Cetakan Pertama, Yoyakarta : Center of Academic Publishing Service.

Riduwan. 2015. Skala Pengukuran Variabel-variabel Penelitian. Cetakan Kesebelas, Bandung : CV Alfabeta.

Riduwan. 2015. Metode \& Teknik Menyusun Proposal Penelitian. Cetakan Ke-6, Bandung : CV Alfabeta.

Team Penyusun. 2017. Panduan Penyusunan Tesis MM Unsika 2017. Edisi Ke-5, Karawang : Uniska .

Ruky, Achmad S. 2016. Strategi, Kebijakan, dan Cara Penataan Upah, Gaji, dan Remunerasi. Cetakan pertama. Jakarta : PT. Intipesan Pariwara.

Riduwan \& Kuncoro, Engkos Achmad. 2014. Cara Mudah Menggunakan dan Memaknai Path Analysis ( Analisa Jalur). Cetakan keenam, Bandung : CV Alfabeta.

Siregar, Sofian. 2013. Metode Penelitian Kuantitatif. Edisi Pertama, Jakarta : Prenadamedia Group.

Uno, Hamzah B. \& Lamatenggo, Nina. 2014. Teori Kinerja dan Pengukurannya. Jakarta : PT. Bumi Aksara.

Fasysica, Magdalena. Towal, Bernlard \& Walangitan, Mac Donald. 2016. Pengaruh Motivasi Kerja, Kompensasi dan Motivasi Kerja terhadap Kepuasan Kerja Karyawan. Jurnal Berkala Ilmiah Efisiensi. Volume 16 no 4. Manado : Universitas Sam Ratulangi.

Heidjrachman, 2002. Manajemen Personalia, Cetakan Sepuluh. Penerbit : BPFE, Yogyakarta.

Hakim, A Khairul. 2011. Pengaruh Kompensasi dan Motivasi Terhadap Produktivitas Pegawai. Jurnal Manajemen \& Bisnis Vol II No 2. ISSN 16937619.

H.M. Burhan Bungin, Metodologi Penelitian Kuantitatif, Jakarta: Prenada Media, 2005, hlm. 75

Sudiarta, I Gede Arya. Indrawati, Ayu Dewi. 2015. Pengaruh Motivasi, Kompensasi Finansial dan Lingkungan Kerja Fisik Terhadap Produktivitas Karyawan 
Pada PT Arta Prima. E-Jurnal Manajemen Univeristas Udayana, Vol 4 no 2. Denpasar.

Mathis, Robert L dan Jackson. 2006. Manajemen Sumber Daya Manusia. Jakarta: Salemba Empat

Martoyo, Susilo. 2007. Manajemen Sumberdaya Manusia. Edisi 5. BPFE. Yogyakarta

Moeheriono. 2012. "Pengukuran Kinerja Berbasis Kompetensi”. Jakarta: Raja Grafindo Persada

Notoatmojo, Soekidjo, (2009). “Pengembangan Sumber Daya Manusia”. Jakarta : PT. Rineka Cipta.

Rivai, Veithzal. 2005. Manajemen Sumber Daya Manusia untuk Perusahaan : dari

Teori ke Praktik. Jakarta : PT Raja Grafindo Persada.

Priyanto, Duwi, (2008). “Mandiri Belajar SPSS”. Yogyakarta : Mediakom.

Simamora, Henry. (2004). “Manajemen Sumber Daya Manusia”. Yogyakarta : STIE YKPN.

Singarimbun Masri dan Efendi Sofian, (2006). “Metode Penelitian Survei”. Jakarta : LP3ES.

Sutrisno, Edy. 2010. Manajemen Sumber Daya Manusia. Edisi 1. Cetakan Kedua.

Prenada Media Group. Jakarta

Santoso, Singgih. (2004). "SPSS Versi 12”. Jakarta : Gramedia Pustaka Utama.

Siagian, Sondang P. 2001. Manajemen Sumber Daya Manusia. Jakarta : Bumi aksara.

Sinungan Muchdarsyah, 2008. Produktivitas Apa dan Bagaimana. Jakarta: PT Bumi Aksara

Stonner, James, A.F. 2002. Manajemen. Edisi II. Prenhalindo ; Jakarta

T Hani Handoko, (2008). “Manajemen Personalia dan Sumber Daya Manusia”. Cetakan Ke 16, Yogyakarta.

Terry, R George. (2005). “Dasar-dasar Manajemen”. Cetakan Ke Sembilan, Jakarta : PT. Bumi Aksara.

73. 